\title{
The New Deal for New Americans: Immigration Status and Mental Health
}

\section{Merve Armağan Boğatekin ${ }^{1}$}

\author{
1 Dr., Istanbul/Turkey \\ ORCID: 0000-0001-7685-6356 \\ E-Mail: \\ mervearmaganuml@gmail.com \\ Corresponding Author: \\ Merve Armağan Boğatekin \\ January 2022 \\ Volume:19 \\ Issue: 45 \\ DOI: $10.26466 / /$ opusjsr.1063389
}

Citation:

Armağan Boğatekin, M. (2022).

The new deal for New

Americans: Immigration status and mental health. OPUS Journal of Society Research, 19(45),

178-184.

\begin{abstract}
Extreme circumstances immigrants experience causes them to have a higher risk for mental health problems. It gets even more severe for refugees than host populations and other migrant groups. Thus, in this paper, mental health disparities between native-born citizens and refugees in the US will be investigated by considering social policies. Firstly, immigration status in the US will be investigated in terms of its relation to mental health. Then, mental health will be examined, and the focus will be on anxiety disorders and depression as these are the two common disorders among refugees. In the following section, Social-Ecological Model will be used as a framework to explain the relationship between immigration status and mental health. The Refugee Act of 1980 and The New Deal for New Americans Act will be used to understand the current political climate in terms of the refugee situation in the US, and we will examine how this has an impact on refugees' mental health. This paper will be concluded after mentioning the obstacles and the recommendations.
\end{abstract}

Key Words: Social Policy, Mental Health, Social-Ecological Model, Refugees, Immigrants.

Öz

Göçmenlerin yaşadığı ekstrem koşullar, ruh sağhlğ̆ı sorunları için daha yüksek riske sahip olmalarına neden olur. Mülteciler için bu durum ev sahibi nüfusa ve diğer göçmen gruplara kıyasla çok daha şiddetlidir. Bu nedenle, bu makalede Amerika Birleşik Devletleri'ndeki yerli vatandaşlar ile mülteciler arasındaki ruh sağhlğ̆ eşitsizlikleri, sosyal politikalar dikkate alınarak detaylıca incelenmiştir. İlk olarak, $A B D^{\prime}$ deki göçmenlik durumu ruh sağllğ̆ ile ilişkisi açısından incelenmiş, daha sonra mülteciler arasında en yaygın görülen iki rahatsızlık olduğu için odak noktası kaygı bozuklukları ve depresyon olarak belirlenmiştir. Sosyal-Ekolojik Model, göç durumu ile ruh sağllğg arasındaki ilişkiyi açıklamak için bir çerçeve olarak kullanılmıştır. Bu kapsamda, Sosyal-Ekolojik Model'in politika ayağını değgerlendirmek adına 1980 Mülteci Yasası ve Yeni Amerikalılar İçin Yeni Düzen Yasası incelenmiş olup, bu yasalar $A B D^{\prime}$ deki mülteci durumuna ilişkin mevcut siyasi iklimi anlamak için kullanılmıştır. Bu gibi sosyal politikaların mültecilerin ruh să̆lığı üzerinde nasıl bir etkisi olduğunu incelediğ̈imiz bu makale, engeller ve önerilerden bahsedildikten sonra sona ermiştir.

Anahtar Kelimeler: Göç, Ruh Sağllğğ, Sosyal Politika, Mülteci, Göçmen. 


\section{Introduction}

Immigration status impacts mental health mainly because of legal status, language and cultural barrier, financial obstacles in accessing healthcare services, and lack of knowledge on how to navigate the complex healthcare system in the US. Immigrants are more likely to get employed in jobs that require low-level skills. This also means that those jobs are more dangerous and hazardous but pay less and usually lack official status recognition and social protection.

A refugee is forced to flee their country due to circumstances such as persecution, war, or violence. They usually cannot return home, or they are afraid of going back. According to The United Nations High Commissioner for Refugees is a United Nations (UNHCR, 2017), the number of forcibly displaced population - which includes individuals who fled for the same reasons but have not passed the border, is 68.5 million, whereas the number of refugees is 25.4 million all around the globe. This trend shows that almost 44.000 people were forced to flee their homes every day in 2017, which directly impacts the US since it has been one of the countries that accept the highest number of refugees all over the world historically. According to the USA for UNHCR (2019), the US has welcomed more than three million refugees since 1975.

Mental health service utilization in immigrant populations is lower than native-born citizens (Kung, 2003). They are also less likely to seek help due to family support, cultural attitudes toward mental health, and language barrier. Social determinants of health have an impact on mental health disparities between native-born citizens and immigrants. Even though very little is known about immigrant mental health and citizenship status, it is apparent that nativity impacts the prevalence of depression and anxiety disorders, especially among adolescent refugees (Filion, 2018). Interestingly, according to Blue and Fenelon (2011), the immigrant paradox occurs as immigrants are more likely to exhibit better health when they first arrive. However, after a while, these positive outcomes fade away in line with the time spent in the US.

\section{Mental Health among Refugees in the US}

The immigration status patterns mental health disorders in a way that many different factors interact. There is a bidirectional relationship with physical health problems or social factors and a causal relationship with others, such as experiences before and during their journey. Research indicates that depression and anxiety disorders are two of the most common mental health disorders among refugees (Cruwys et al., 2014). For example, according to a study about Karenni refugees, their depression and anxiety proportions were more than $40 \%$ for those residing along the Burmese-Thai border, whereas it was 7$10 \%$ for the general US population (Vonnahme, Lankau, Ao, Shetty and Cardozo, 2015). Authors collected data from the resettled refugees in the US and found that $27 \%$ of those refugees had at least one mental health condition, and $45 \%$ of them experienced symptoms of multiple conditions. Besides, they found that refugees who experience symptoms of PTSD also experienced symptoms of anxiety, depression, or both. Thus, there is a high risk of comorbidity here.

Everybody might experience anxiety from time to time, and it can even be helpful for individuals as it might be a source of motivation to solve daily problems. However, anxiety disorders are much more intense and long-lasting when compared to everyday anxiety. According to DSM-5 (2013), It also interferes with the individual's habits, work schedule, and even relationships. There are different types of anxiety disorders, such as phobias, panic disorder, generalized anxiety disorder, and post-traumatic stress disorder. Their symptoms might be observed in different forms, including physical, behavioral, and psychological.

Physical symptoms might be cardiovascular, neurological, respiratory, or musculoskeletal (Kitchener and Jorm, 2006). Also, psychological symptoms might range from irritability to restlessness. In addition, behavioral symptoms might include avoidance, obsessive or compulsive behaviors. It is important to note that refugees usually self-report poor health, and it is believed to be associated with depression as a result of 
somatization (Vonnahme et al., 2015). According to Katon and Kleinman (1982), particular cultures might impact a person's likelihood of somatizing depression as it may not be culturally acceptable to express psychological disturbances verbally.

According to DSM-5 (2013), major depressive disorder lasts for at least two weeks and interferes with daily life. Depression is an unusual, sad mood that continues for more than 14 days. Some symptoms include tiredness, feeling worthless, suicidal thoughts, difficulties with sleeping, and changes in eating habits. Refugees may selfcriticize and self-blame during this period, and one can observe a loss of interest in personal appearance and sexual desire. It is believed to be a result of changes in neurotransmitters in the brain. Thus, it is often treated with medications (antidepressants), which activate serotonin's secretion in the brain, a mood-regulating brain chemical.

\section{Social-Ecological Model and Refugee Health}

Social-Ecological Model (SEM) will be used to investigate the relationship between immigration status and mental health in detail (See Appendix A). SEM is a theory-based framework to understand the levels of a social system and how individuals and the system's environment interact in terms of health promotion (CDC, 2014). SEM levels are as follows: Individual, interpersonal, community, organizational, policy/enabling environment. In order to make an effective intervention, it is essential to use this approach, which considers different levels of factors (Figure 1). Therefore, in this paper, we aim to use this framework and examine the New Deal for New Americans policy on five different layers.

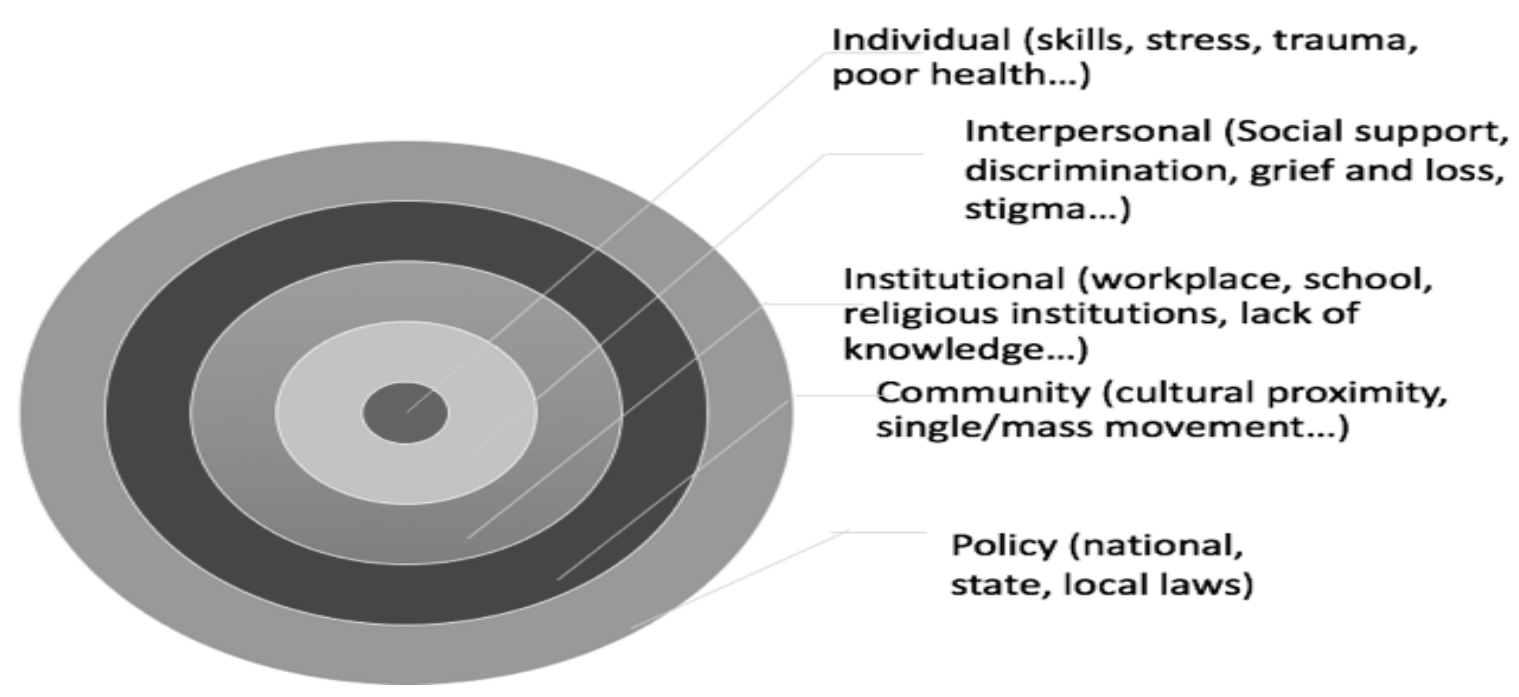

Figure 1. Levels of the Social-ecological Model

On an individual level, the model mentions an individual (i.e., age, gender, religious identity, etc.). Those characteristics might influence their stress levels and eventually impair their overall well-being. Secondly, social support systems (i.e., family, friends, religious networks) are examined on an interpersonal level regarding their influence. The interpersonal level is vital as refugees have their social support systems disrupted, and they usually are trying to establish a new social support system in the country they settled in.

Furthermore, on an organizational level, social institutions should be active in terms of refugee health as they also impact behaviors on the individual and community levels. Last but not least, the policy/enabling environment plays a crucial role in individual behaviors. Local, state, national, and global laws and policies regarding health and refugees influence their psychological and physical well-being. Two different federal laws regarding refugees will be investigated in the following section. 


\section{Bidirectional Relationship Between Migration and Health}

There is a bidirectional relationship between immigration status and mental health disorders (Figure 2). Refugees are exposed to trauma and stressors before, during, and after their migratory process. Their experiences in their home countries usually consist of traumatic events, grief, and loss. Besides, during the journey, they might be subject to different types of abuse, and their experiences vary based on geographical proximity to their destination and what kind of ways they are using to arrive there. Once they arrive, they are subject to different types of anxiety-provoking situations and stressors. This includes their work-related circumstances as it brings some psychological and physical burden to refugees, especially since they are hired in low-status jobs that usually pay less. Also, refugees have difficulty adjusting to the new culture and environment, which becomes a source of stress. Refugees usually experience social exclusion, and perceived discrimination increases their levels of stress. This factor is doubled with their lifestyle factors as they usually have to cope with the language barrier, especially when they first arrive.

These factors usually have an impact on physical well-being and health behaviors too. For instance, smoking and drinking behaviors are more common among immigrant populations (Záleská et al., 2014). Thus, mental health disorders are complicated and not easy to treat as biopsychosocial factors cause them. According to the biopsychosocial model, mental health problems usually occur because of biological, social, and psychological factors. We can see how these factors are interconnected (Figure 2).

This paper's most critical SEM level is the policy/enabling environment, which consists of policy-making and other leadership types for health promotion. Refugee Act of 1980 and The New Deal for New Americans Act, which was proposed in 2019, are two critical examples to it in terms of refugee health.

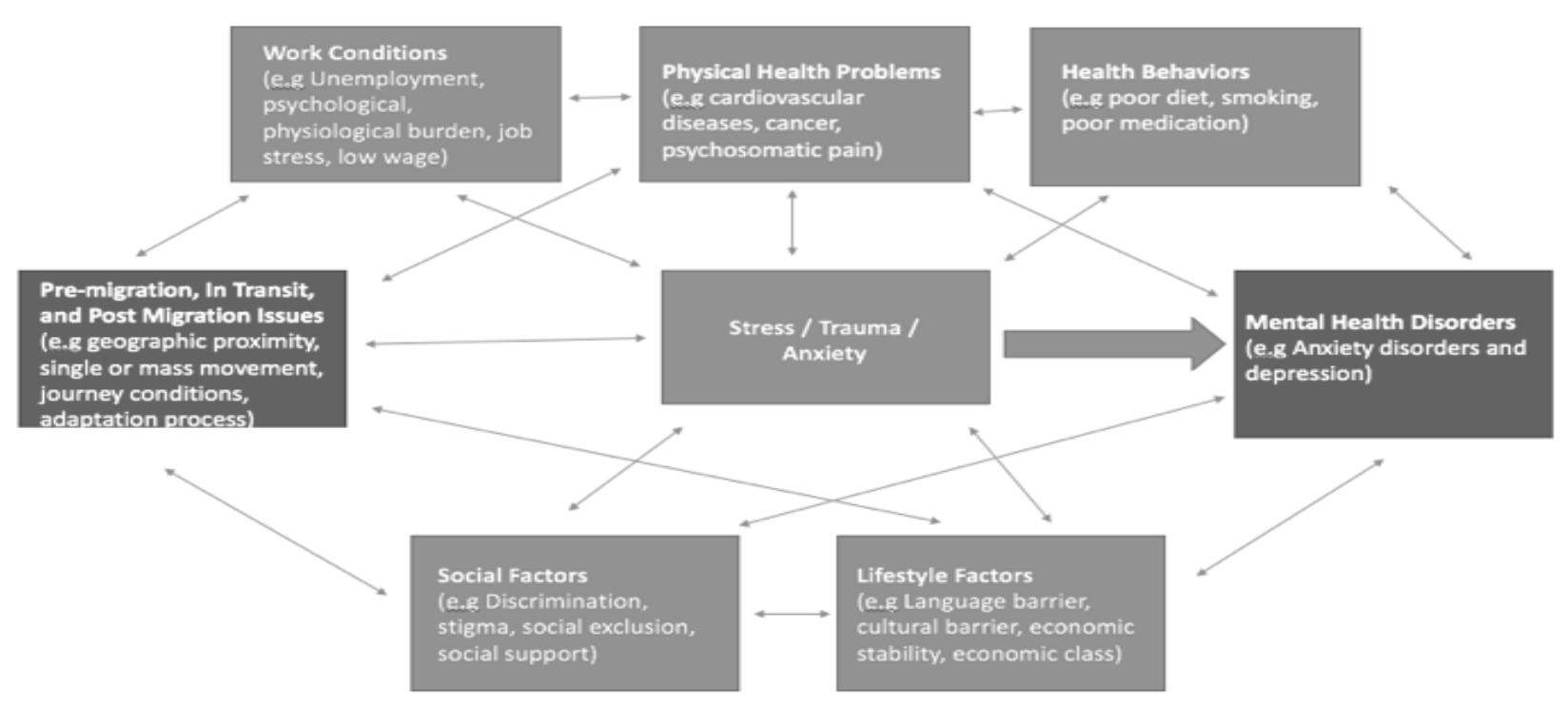

Figure 2. Model of the Relationship Between Migration Issues and Mental Health Disorders based on SocialEcological Model

The Refugee Act of 1980 and The New Deal for New Americans Act

The United States Refugee Act of 1980 is a Public Law (96-212) related to how the office should 
ensure refugees to be economically self-sufficient by providing resources for training, cash assistance, etc. This law is used as a base for most refugee resettlement programs in the country and mentions that the US policy aims to encourage all nations to provide help to refugees to the fullest extent possible. Thus, it helped reduce the stress level for refugees by reducing many factors such as unemployment, language barrier, and economic instability. As mentioned before, SEM investigates issues on five different layers and policies are the fifth layer this model emphasized. Therefore, the two Acts we will be covering in this paper will examine the situation on the fifth layer. This idea aligns well with the differential exposure hypothesis, which is an essential contribution to the health and stress literature, as it states that members of disadvantaged groups experience more stressors than advantaged group members (Denton et al., 2004). This is relevant as refugees are exposed to more cumulative and chronic stress, which eventually hurts their physical and mental health. Thus, the initiative investigated above would help reduce the stress level refugees in the US have experienced just as the SEM suggests.

On the other hand, the current political climate is likely to impact the well-being of refugees negatively. A new Public Charge rule that the Trump administration proposed on October 15, 2019, aimed to prevent legal immigrants who use government benefits they are legally entitled to, such as food assistance or services such as Medicaid, from receiving green cards/permanent residency. As a result, lower-income migrants would have more difficulty in obtaining US citizenship. The draft of the proposal was first published in September 2019 and received much critique. The attacks on immigration, which also include redefining asylum, might have become a stress factor for immigrants. Even though refugees and asylum seekers were exemptions to this rule, several other incidents, such as Executive Order 13769 (Protecting the Nation from Foreign Terrorist Entry into the United States, also known as the Muslim ban/travel ban) which might lead refugees to get overwhelmed. It is also important to note that on September 26, 2019, the White House announced that in 2020, refugee admissions to the country would be limited to 18,000 . Furthermore, Executive Order 13888 (Enhancing State and Local Involvement in Refugee Resettlement) gave state and local authorities the power to deny refugee resettlement in their particular area.

After these decisions about immigrants and refugees, several representatives introduced new federal legislation on October 30, 2019: The New Deal for New Americans Act. It was proposed to strengthen the infrastructure of the immigration system in the country. This bill aims to decrease the citizenship application fee and increase citizenship opportunities for refugees and immigrants. This act aims to establish assistance programs for immigrants and refugees to overcome challenges such as employment, obtaining citizenship, and the language barrier. Also, 110,000 refugees are expected to be welcomed in the country through refugee resettlement programs per fiscal year instead of 18,000, and they will receive the necessary legal support once they arrive. The bill emphasizes that refugees will be welcomed in inclusive and welcoming neighborhoods, which makes this bill also helpful in reducing discrimination and increasing social support. Thirdly, this bill ensures that everybody will have equitable access to citizenship, decreasing refugees' stress levels. They will also have access to English language learning programs and workforce development programs to support their education and economic participation in the country. Clearly, all these points emphasized in the bill help overcome obstacles refugees face and reduce their stress levels. By doing so, eventually, refugees in the US would have better psychological and physical well-being.

\section{Obstacles and Recommendations for Better Health Outcomes}

There might be some obstacles that hamper these initiatives and create difficulty in implementing it. Firstly, there was political instability in the US as the Trump administration had an entirely different immigration policy approach. Even though the Biden administration seems more welcoming, the previous administration had long-lasting effects 
coupled with the effects of the Covid-19 pandemic. This lack of political will might make it harder to implement the initiative and let refugees have a smoother adjustment process as there will be resistance from regulatory bodies. Moreover, all the bill's points are costly and will burden the US government in the short-term. Its costeffectiveness will be questioned, and some recommendations in the bill might not be accepted.

Furthermore, it is hard to find data on refugee mental health from governmental sources. Even though these initiatives would help reduce the stress levels and eventually help increase the overall well-being among refugees, most refugees still lack access to mental health services as it is hard to detect the problem without proper data. Even those who have access to mental health services in various settings might deal with the language barrier and lack confidence in seeking help when third parties (interpreters) get involved. Another obstacle is the lack of knowledge on how to navigate the system, especially when it comes to mental health services and counseling (Jentsch et al., 2007).

Social barriers such as stigmatization (surrounding psychological disorders), lack of awareness, fear of reporting problems, discrimination, or mistreatment might become obstacles to access to treatment for refugees (Samari, 2017). Also, refugees lack immunization and experience poor living conditions (Lifson et al., 2001).

They also might have inadequate access to food and water, and these circumstances may exacerbate the situation. These stressful conditions coupled with an impaired social support system, fear of deportation, or current political climate might have many negative health consequences for refugees in the US.

Thus, the first recommendation would be to increase the advocacy efforts as it is a crucial component of overcoming the aforementioned barriers. Advocacy can be defined as an organized effort to push the leadership toward achieving a particular goal, such as developing new policies or changing existing ones. It has utmost importance to develop an advocacy strategy and let decisionmakers know about the situation and how urgent it is. The New Deal for New Americans is an example of the results of those efforts.

Secondly, the importance of collective action and community involvement should be acknowledged. Thus, public education and stimulating community dialogue are necessary to overcome those barriers. Once knowledge increases, individual attitudes would change, resulting in reduced stigma in terms of mental health. Then demand would increase for mental health services, and people would seek help for their psychological symptoms. In conclusion, it is not enough to work on material restoration. We should work on psychological restoration as well in order to prevent future mental health problems.

\section{Conclusion}

The social-ecological system requires changing individual behaviors in five different layers, which start from the individual and continue with the household, community, organizational, and policy level. Thus, individuals need to understand the urgent need for refugees' mental health resources and have a supportive family environment that encourages them to seek help. In this paper, we investigated the fifth layer of the SEM, policy-level changes in individual behavior by examining two different acts related to the refugee situation.

As it is pictured, SEM helps us understand how complicated this issue is but, at the same time, gives directions to examine the problem and solve it. Thus, working in all five different layers of the problem and making prevention and then intervention programs a priority, we can help refugees have better psychological and physical health in a time in which anti-refugee sentiments are on the rise due to political climate and instability.

\section{References}

Acevedo-Garcia, D., Bates, L. M., Osypuk, T. L., \& McArdle, N. (2010). The effect of immigrant generation and duration on self-rated health among US adults 2003-2007. Social science $\mathcal{E}$ medicine, 71(6), 1161-1172. 
American Psychiatric Association. (2013). Diagnostic and statistical manual of mental disorders (DSM-5®). American Psychiatric Pub.

Bhugra, D., Gupta, S., Bhui, K., Craig, T. O. M., Dogra, N., Ingleby, J. D., ... \& Stompe, T. (2011). WPA guidance on mental health and mental health care in migrants. World Psychiatry, 10, 2-10. https://doi.org/10.1002/j.2051-

5545.2011.tb00002.x

Blue, L., \& Fenelon, A. (2011). Explaining low mortality among US immigrants relative to native-born Americans: the role of smoking. International journal of epidemiology, 40(3), 786793.

Centers for Disease Control and Prevention (CDC), the social-ecological model: A framework for prevention.http://www.cdc.gov/violenceprevent ion/overview/social-ecologicalmodel.html (retrieved November 9, 2019).

Cruwys, T., Haslam, S. A., Dingle, G. A., Haslam, C., \& Jetten, J. (2014). Depression and social identity: An integrative review. Personality and Social Psychology Review, 18(3), 215-238.

Denton, M., Prus, S., \& Walters, V. (2004). Gender differences in health: A Canadian study of the psychosocial, structural and behavioral determinants of health. Social science $\mathcal{E}$ medicine, 58(12), 2585-2600.

Filion, N., Fenelon, A., \& Boudreaux, M. (2018). Immigration, citizenship, and the mental health of adolescents. Plos one, 13(5), e0196859.

Jentsch, B., Durham, R., Hundley, V., \& Hussein, J. (2007). Creating consumer satisfaction in maternity care: The neglected needs of migrants, asylum seekers, and refugees. International Journal of Consumer Studies, 31(2), 128-134.

Lifson, A. R., Thai, D., \& Hang, K. (2001). Lack of immunization documentation in Minnesota refugees: challenges for refugee preventive health care. Journal of immigrant health, 3(1), 47-52. 